\title{
Islamisasi Model al-Faruqi dan Penerapannya dalam Ilmu Ekonomi Islam di Indonesia (Suatu Kritik Epistemik)
}

Oleh: Yusdani*

\begin{abstract}
The following article tries to investigate the knowledge islamization of al-Faruqi and its implementation in Islamic Economics in Indonesia. But the problem in this connection is does islamization of knowledge can responsible either in term religion or that of academical discourse in particular in economics? In fact, the islamization implementation in muslim economic in Indonesia tends more to supply market demand than that of Islamic Economics as science. Thus, there is the orientation deviation in Islamic Economics in Indonesia from academic to political sphere.
\end{abstract}

Keywords: islamisasi, al-Faruqi, ekonomi Islam, pasar, dan masyarakat

\section{Pendahuluan}

Prestasi terbesar Barat adalah keberhasilannya dalam mengembangkan ilmu pengetahuan dan teknologi secara positif dapat memberikan kemudahan hidup bagi umat manusia dan bisa dinikmati manfaatnya oleh umat manusia saat ini. Namun, diakui juga bahwa dampak negatif keberhasilan iptek ini dapat mendatangkan malapetaka kemanusiaan terbesar seperti Perang Dunia Kedua.

* Yusdani adalah dosen tetap FIAI Universitas Islam Indonesia Yogyakarta, email: yusdanimsi@yahoo.com 
Karena dengan kemajuan iptek dapat dikembangkan juga senjata pemusnah berat dan bertolak belakang dengan rasa keadilan umat manusia jika dipergunakan untuk merusak dan menghancurkan tatanan kehidupan semua makhluk hidup ciptaan Tuhan, hal ini sudah tentu bertentangan dengan nilai-nilai agama. ${ }^{1}$ Dalam konteks ini, munculnya wacana Islamisasi Ilmu Pengetahuan yang ramai diperbincangkan pada tahun 1970-an oleh berbagai sarjana Muslim dari berbagai disiplin ilmu, dapat dibaca sebagai sebuah kontra-hegemoni ataupun diskursus perlawanan.

Gagasan Islamisasi Ilmu Pengetahuan yang dikemukakan oleh para sarjana muslim sekalipun terdapat titik-titik persamaan, juga ada garis perbedaan di antara mereka. Misalnya antara Alatas ${ }^{2}$ dan al-Faruqi. ${ }^{3}$ Al-Faruqi tampaknya lebih bisa

${ }^{1}$ Chairil Anwar (2000), Islam dan Tantangan Kemanusiaan Abad XXI, (Yogyakarta: Pustaka Pelajar), p.1 dan 16; R.H.A. Sahirul Alim (1999), Menguak Keterpaduan Sains, Teknologi dan Islam (Yogyakarta: Titian Ilahi Press), p.67-68.

${ }^{2}$ Konsep dasar Islamisasi Ilmu Pengetahuan ala Alatas bisa dibaca misalnya dalam bukunya Islam \& Secularism. Bagi Alatas misalnya, Islamisasi Ilmu Pengetahuan mengacu kepada upaya mengeliminir unsur-unsur serta konsep-konsep pokok yang membentuk kebudayaan dan peradaban Barat, khususnya dalam ilmu-ilmu kemanusiaan. Tercakup dalam unsur-unsur dan konsep ini adalah cara pandang terhadap realitas yang dualistik, doktrin humanisme, serta tekanan kepada drama dan tragedi dalam kehidupan rohani sekaligus penguasaan terhadapnya. Setelah proses ini dilalui, langkah berikutnya adalah menanamkan unsur-unsur dan konsep pokok keislaman. Sehingga dengan demikian akan terbentuk ilmu pengetahuan yang benar; ilmu pengetahuan yang selaras dengan fitrah. Dalam bahasa lain, Islamisasi Ilmu Pengetahuan ala Alatas dapat ditangkap sebagai upaya pembebasan ilmu pengetahuan dari pemahaman berasaskan ideologi, makna serta ungkapan sekuler Lihat: Syed Farid Alatas (1994), "Agama dan Ilmu-ilmu Sosial”, Jurnal Ilmu dan Kebudayaan Ulumul Qur'an No. 2 Vol. 5 Tahun 1994.

${ }^{3}$ Isma'il Raji al Faruqi, "Islamization of Knowledge: Principles, and Prospective”, dalam Islam: Source and Purpose of Knowledge, Herndon, Virginia, USA: International Institute of Islamic Thought, 1988. Menurut Ismail al Faruqi, Islamisasi Ilmu Pengetahuan dimaknai sebagai upaya pengintegrasian disipilin-disiplin ilmu modern dengan khazanah warisan Islam. Langkah pertama dari upaya ini adalah dengan menguasai seluruh disiplin ilmu modern, memahaminya secara menyeluruh, dan mencapai tingkatan tertinggi yang ditawarkannya. Setelah prasyarat ini dipenuhi, tahap berikutnya adalah melakukan eliminasi, mengubah, menginterpretasikan ulang dan mengadaptasikan komponen-komponennya dengan pandangan dunia Islam dan nilai-nilai yang tercakup di dalamnya. Dalam deskripsi yang lebih jelas, Islamisasi Ilmu Pengetahuan menurut al-Faruqi adalah "upaya mewujudkan prinsip-prinsip Islam dalam metodologinya, strateginya, dan dalam apa yang dikatakan sebagai data-data, problemnya, tujuan-tujuannya dan aspirasi-aspirasinya." Terkait dengan ini setiap disiplin ilmu mesti dirumuskan sejak awal dengan mengkaitkan Islam sebagai kesatuan yang membentuk tauhid, yaitu kesatuan pengetahuan, kesatuan kehidupan dan kesatuan sejarah. Ia harus didefinisikan dengan cara baru, data-datanya diatur, kesimpulan-kesimpulan dan tujuan-tujuannya dinilai dan dipikir ulang dalam bentuk yang dikehendaki Islam Syed Farid Alatas. 
menerima konstruk ilmu pengetahuan modern, yang penting baginya adalah penguasaan terhadap prinsip-prinsip Islam yang dengannya sarjana Muslim bisa membaca dan menafsirkan konstruk ilmu pengetahuan modern tersebut dengan cara yang berbeda.

Berbeda dengan al-Faruqi, Alatas di samping pengaruh sufisme yang cukup kuat, antara lain dengan gagasan digunakannya takwil dalam kerangka Islamisasi Ilmu Pengetahuannya, juga lebih menekankan pada dikedepankannya genuitas yang digali dari tradisi lokal. Dalam pandangan Alatas, peradaban Islam klasik telah cukup lama berinteraksi dengan peradaban lain, sehingga umat Islam sudah memiliki kapasitas untuk mengembangkan bangunan ilmu pengetahuan sendiri. Tanpa bantuan ilmu pengetahuan Barat modern, diyakini dengan merujuk pada khazanahnya sendiri umat Islam akan mampu menciptakan kebangkitan peradaban. Sepertinya, perbedaan semacam ini, di samping faktor-faktor personal, yang membuat keduanya memilih mengembangkan gagasannya di lembaga yang berbeda. Jika Alatas kemudian berkutat di ISTAC yang berbasis di Malaysia dan kini diberitakan bubar, al-Faruqi menyebarkan gagasannya lewat International Institute of Islamic Thought (IIIT) yang berbasis di Amerika Serikat. ${ }^{4}$

Pokok bahasan tulisan ini, lebih terfokus pada gagasan yang dikembangkan Ismail Raji al-Faruqi dengan para koleganya di IIIT. Model Islamisasi ala Faruqi dan IIIT tampaknya dapat dipandang sebagai arus dominan dalam khazanah Islamisasi Ilmu Pengetahuan dewasa ini, khususnya di Indonesia. Terlebih, model ini pulalah yang bisa dirujuk jika kita mencoba menganalisis beberapa implementasi praktis Islamisasi Ilmu Pengetahuan dalam bidang ekonomi, yaitu dalam bentuk institusi-institusi keuangan berlabel Islam, seperti Bank Islam, Asuransi Islam dan Pasar Modal Islam. Sedikit telaah juga akan dilakukan melalui institusi-institusi tersebut.

${ }^{4}$ Selain Alatas dan al-Faruqi, tentu ada beberapa nama lain yang bisa disebutkan, semisal Seyyed Hosein Nasr, yang dengan kerangka perenialisnya tentu memiliki gagasan berbeda untuk isu sejenis. Demikian pula dengan Timur Kuran, ekonom asal Turki yang juga berdiam di Amerika Serikat dan dikenal memiliki pendekatan berbeda. Timur Kuran di paragraf akhir artikelnya yang berjudul "The Religious Undercurrents in Muslim Economic Grievances" menyatakan: "Regardless of their faith or creed, the world's intellectuals can also help out by abandoning the relativist strains of modern multiculturalism. Although all major cultures, including those associated with Islam, offer much that is valuable and instructive, they are not equally successful at producing viable economic solutions. In particular, whatever other comforts Islamism gives its adherents, it is clearly an inferior instrument of economic development. In fact, some of its variants, including that of the Taliban, have proven to be positively harmful, even hostile, to material prosperity. The laudable goal of cherishing the achievements of diverse cultures and respecting cultural differences does not absolve us of the responsibility to acknowledge failures, deadends, and dangers where they are noticed.". 


\section{Latar Sosiologis Islamisasi Ilmu Pengetahuan}

Gagasan atau gerakan Islamisasi Ilmu Pengetahuan merupakan salah satu upaya menjawab tantangan modernitas yang melanda umat Islam. Ada semacam guncangan di kalangan umat Islam, menyaksikan realitas yang menempatkan diri mereka pada sudut buram sejarah. Di balik kemegahan peradaban Barat yang terus melaju pasca Renaissance, sebagian besar dunia Islam secara kontras justru termegap-megap dalam sesuatu yang dalam visi modern disebut perangkap kemunduran dan keterbelakangan. Terlebih, masih segar dalam ingatan kolektif umat Islam bahwa beberapa abad lampau mereka pernah memegang supremasi peradaban dengan dominasi yang kukuh pada ranah kebudayaan, politik maupun ekonomi. Dengan simbol kekuasaan politik Kekhalifahan Abbassiyah di Bagdad, Kekhalifahan Umayyah di Cordova, mereka pernah berada pada posisi superior dibandingkan masyarakat Eropa yang pada masa itu justru terkungkungi masamasa sejarah yang gelap.

Membaca realitas di atas, Abdul Hamid Abu Sulayman misalnya mengemukakan betapa krisis dengan dimensi yang kompleks memang melanda Umat Islam. Ia mendata beberapa isu terkait dengan krisis ini adalah kemunduran Umat, kelemahan Umat, stagnasi Intelektual di kalangan Umat, absennya Ijtihad di kalangan Umat, tiadanya kemajuan kultural di kalangan Umat, umat telah bergeser dan menjadi terasing dari norma-norma dasar peradaban Islam. ${ }^{5}$

Sementara itu, Ismail Raji al Faruqi mengungkapkan apa yang dia namakan "malaise of the Ummah". Dengan kegetiran ia menyatakan, tidak ada masyarakat lain yang tertaklukkan dan begitu dihinakan sebagaimana umat Islam. Kaum Muslim telah dikalahkan, dibunuh secara massal, dirampok tanah dan kekayaannya, juga dirampas hidup dan harapannya. Mereka terjajah dan terksploitasi. Bahkan juga tersekularisasi, terbaratkan dan dideislamisasi baik oleh agen internal maupun eksternal musuh-musuh mereka. Mereka adalah korban ketidakadilan dan agresi. Tak hanya itu, mereka juga dinisbati stereotypestereotype yang menyakitkan: agresif, destruktif, tak kenal hukum, teroris, tidak beradab, fanatik, fundamentalis, kolot dan ketinggalan zaman. ${ }^{6}$

Akibat malaise di atas, umat Islam secara politik kemudian terpecah belah menjadi puluhan negara bangsa yang saling berbenturan. Bahkan

${ }^{5}$ Abdul Hamid Abu Sulayman (1998), "Islamization of Knowledge: A New Approach Toward Reform of Contemporary Knowledge", dalam Islam: Source and Purpose of Knowledge, Herndon, Virginia, USA: International Institute of Islamic Thought, p. 93. Dalam bukunya Crisis in the Muslim Mind, Abu Sulayman juga menyatakan hal senada, "No one studying the ummah will have difficulty in discerning the present backwardness of its culture, its political degredation, and its human suffering, regardless of its human and material resources and inspite of its value and principles." Lihat Abdul Hamid Abu Sulayman (1993), Crisis in the Muslim Mind, (Herndon, VA: IIIT, 1993), p. 1.

${ }^{6}$ Ismail Raji al Faruqi, Islamization..... p. 18. 
secara internal, di setiap negara tersebut dipecah belah lagi menjadi berbagai kelompok, kelompok-kelompok tertentu diarahkan oleh kaum kolonialis untuk menghegemoni kelompok llainnya. Lebih tragis, kaum kolonialis juga menanamkan pemerintah yang "asing" ke dalam tubuh umat Islam sehingga energi mereka teralihkan dari upaya rekonstruksi. Sebaliknya mereka diarahkan pada pergolakan yang sia-sia. ${ }^{7}$

Secara ekonomi, umat Islam juga terjebak dalam keterbelakangan sebagai negara yang belum berkembang. Sejumlah besar penduduk di negeri-negeri Muslim berada dalam keadaan buta huruf. Produksi barang dan jasa mereka tak mencukupi, karenanya mereka mesti mengimpor barang jadi dari negaranegara yang dulu menjadi kelompok kolonialis. Demikian pula, sekalipun banyak di antara negeri-negeri Muslim yang dikarunia kekayaan sumber daya alam, kekayaan tersebut tak bisa dimanfaatkan untuk membangun kemampuan potensia mereka. ${ }^{8}$

Sementara pada ranah budaya dan agama, beragam persoalan muncul sebagai akibat kebodohan dan keterbelakangan umat Islam. Rata-rata umat Islam menjerumuskan diri mereka pada ketenangan iman yang buta. Mereka memilih terperangkap pada literalisme dan legalisme, atau menundukkan jiwa mereka kepada syaikh mereka. Umat Islam juga kemudian menjadi terasing dari warisan sejarahnya, terutama ketika sistem pendidikan modern yang sekuler mulai diberlakukan di banyak negeri Muslim. Pembaratan benar-benar merajalela. Moral kaum Muslimin termasuk kalangan wanitanya memasuki tahap degradasi.?

Berangkat dari kesadaran dan identifikasi terhadap beragam persoalan di atas, sarjana Muslim seperti al Faruqi dan Abdul Hamid Abu Sulayman mengajukan tesis, bahwa persoalan mendasarnya terletak pada krisis pemikiran yang menjangkiti kaum Muslimin. Dalam pandangan al Faruqi, krisis multidimensi yang melanda umat Islam, bisa dirujukkan pada sistem pendidikan sekuler yang diadopsi oleh berbagai negeri Muslim, akibatnya sekularisasi dan westernisasi merebak dengan cepat di kalangan umat Islam, lebih lanjutnya, fenomena de-Islamisasi terkikisnya nilai-nilai Islam dari kalangan Muslim - menjadi tak terelakkan. Persoalan kedua, umat Islam pun pada akhirnya kehilangan visi masa depan yang selaras dengan norma-norma agama mereka.

Sementara menurut analisis Abu Sulayman, krisis umat Islam berawal saat perimbangan kekuatan bergeser ke Barat, mereka tak bisa menunjukkan semangat berkorban dan keihklasan yang akan membuat mereka sanggup mempertahankan bukan hanya tanah melainkan juga nilai-nilai yang mereka anut. Hilangnya kepercayaan kepada nilai-nilai moral dan spiritual mereka sendiri, membuat upaya melawan agresi Barat hanya berujung pada pertumpahan darah, kekacauan
${ }^{7}$ Ibid, p. 19.
${ }^{8}$ Ibid, p. 20.
${ }^{9}$ Ibid, p. 21-22. 
Yusdani: Islamisasi Model ...

ekonomi dan kemerosotan di segenap sisi kehidupan. ${ }^{10}$

Umat Islam menurut Abu Sulayman seiring dengan perjalanan waktu, mulai mengalami kemerosotan pengetahuan dan karakter. Hal ini kemudian diiringi dengan kemunduran pada wilayah kebudayaan dan intelektual. Kualitas dan nilai-nilai moral semacam kompetensi, energi, inisiatif, keseriusan, kreativitas dan kebijaksanaan, menghilang. ${ }^{11}$

Mengapa semua ini terjadi? Abu Sulayman menjawab, penyebabnya adalah terpecahnya kepemimpinan dan munculnya krisis dalam pemikiran Islam. Menyangkut yang terakhir, Abu Sulayman menyebutkan bahwa masalahnya terletak pada ketidakmampuan para pemikir Muslim untuk memahami hakikat perubahan yang terkandung dalam pengetahuan, kebudayaan dan peradaban dunia modern. Mereka juga gagal memposisikan secara tepat kekuatan sumbersumber pengetahuan Islam dan belajar dari masa lalu. ${ }^{12}$

Kiranya, pada konteks inilah gagasan Islamisasi Ilmu Pengetahuan kemudian dimunculkan. Ia kurang lebih diarahkan pada pembersihan pemikiran umat Islam dari racun-racun modernisme dan sekularisme yang disebarkan melalui lembaga pendidikan ala Barat. Sebuah bangunan keilmuan yang lebih selaras dengan norma dasar agama dan nilai-nilai keimanan, perlu ditata setahap demi setahap dan dijadikan pilihan bagi para sarjana Muslim. ${ }^{13}$ Dengan demikian, diandaikan integritas sebagai umat akan kembali terwujud. Karakter moral dan intelektual yang dulu runtuh akan bangkit kembali. Pada akhirnya, umat Islampun bisa kembali membangun peradaban yang segemilang dan sesuperior di masa lalu. ${ }^{14}$

${ }^{10}$ Abdul Hamid Abu Sulayman, Islamization .... p.95.

${ }^{11}$ Ibid, p. 95.

${ }^{12}$ Ibid, p.98. Menyangkut hal ini, perlu ditegaskan bahwa Abu Sulayman meyakini bahwa kembali para orisinalitas Islam merupakan satu-satunya solusi. Ia menyatakan, “ As its name indicates, this is an approach based on Islam in terms of objectives, beliefs, values, and ideas. This is because the ummah for which growth, positive action, and reform are intended is Islamic in its beliefs, values, and intellectual and psychological make up. Thus there is no way to motivate it if this basic truth about its personality, hidden strength, and motives is ignored." Abdul Hamid Abu Sulayman, Crisis in the Muslim Mind, p. 17-18.

${ }^{13}$ Abu Sulayman menyatakan, "the crisis of ummah is not one of capabilities and resources, but rather one of concepts. This conceptual crisis is not a acrisis of beliefs, values or principles, but rather o long-standing crisis of thought and methodology brought on by change in the ummah's political foundations and the resultant distancing the intellectual leadership from any sort of societal responsibility." Ibid, p. 35.

${ }^{14}$ Dalam pandangan M.A. Kazi misalnya, kejayaan umat Islam ini berlangsung pada 5 abad pertama sejarah umat Islam yang diawali peristiwa hijrah, kemudian hadir lagi pada abad 8 - 12. Dalam pandangan M.A. Kazi, pada masa inilah umat Islam mengalami kebangkitan secara fenomenal dan pencapaian luar biasa di bidang pemikiran. Lihat M.A. Kazi (1988), Islamization of Modern Science and Technology dalam Islam: Source and Purpose of Knowledge, (Herndon, Virginia, USA: International Institute of Islamic Thought),p. 179. 
Ketertindasan secara politik, keterbelakangan secara ekonomi, dan degradasi secara budaya dan agama bisa diatasi. Dalam bahasa teologis, kedudukan umat Islam sebagai "khoiro ummah" (ummat terbaik) dan "ummatan wasathon" (ummat penengah) bisa benar-benar direalisasikan di muka bumi.

\section{Kasus Islamisasi Ilmu Ekonomi di Indonesia}

Ikhtiar meng-Islam-kan ilmu pengetahuan, kiranya menjadi bagian penting tradisi intelektual kaum Muslim modern. Khususnya di kalangan generasi muda yang bersekolah dan mempelajari berbagai teori ilmu pengetahuan Barat modern di lembaga-lembaga pendidikan sekuler di Indonesia maupun di luar negeri. Seiring dengan gerakan "kembali ke Islam" yang marak di kampus-kampus semenjak tahun 1980-an, gerakan Islamisasi Ilmu Pengetahuan menjadi semacam cermin kerinduan para intelektual dan ilmuan Muslim modern terhadap sesuatu yang "khas" milik mereka. Gerakan ini juga menggambarkan tekad mereka untuk menerapkan ajaran Islam yang diyakini kaafah, syaamil dan kaamil, sempurna dan mencakup segalanya. Dan tentu saja, kesadaran akan "kejayaan umat Islam di masa lalu" menjadi bagian inheren dari gerakan ini.

Pada tingkat disiplin ilmu, agaknya ekonomilah ${ }^{15}$ yang paling banyak dijadikan lahan untuk mengujicoba model Islamisasi Ilmu Pengetahuan. Tokohtokoh dalam bidang ekonomi, beberapa nama yang cukup populer adalah $\mathrm{M}$. Amin Aziz, M. Syafi'i Antonio dan Adiwarman Karim.

Kasus Islamisasi Ilmu Pengetahuan pada disiplin ekonomi, cukup menarik untuk diamati. Sebab ia tak hanya berhenti pada tataran akademis dan perdebatan metodologis, melainkan juga masuk ke wilayah praktis. Kita tahu misalnya, bahwa sistem perbankan non-bunga yang dilandaskan pada konsep Ekonomi Syari'ah atau Ekonomi Islam sebagaimana yang digagaskan Amin Aziz, Syafi'i Antonio dan Adiwarman Karim, kini secara sah diakui sebagai bagian dari sistem perbankan nasional Indonesia. Terkait dengan ini, ada biro khusus di Bank Indonesia yang menangani perbankan tanpa bunga.

Di samping itu, marak bermunculan institusi-institusi ekonomi lain yang berlabelkan Islam atau Syari'ah: Asuransi Syari'ah, Multilevel Marketing (MLM) Syari'ah bahkan juga perusahaan percetakan dan toko swalayan Islam. Ada satu kesamaan mendasar dari kesemua institusi di atas. Mereka coba menerapkan sistem ekonomi yang diyakini sesuai dengan ajaran Islam. Tujuan mereka dinyatakan tak hanya untuk meraih keuntungan finansial, melainkan juga untuk berdakwah dan meraih ridhlo Allah.

Pada titik ini, kita sebetulnya bisa melihat semacam kesenjangan. Jika gerakan Islamisasi Ilmu Pengetahuan pada level akademis sebagaimana

${ }^{15}$ Di lapangan psikologi dapat dikenal nama-nama seperti Hanna Djumhana Bustaman, Jamaludin Ancok maupun Zakiyah Darajat dan lain-lain. 
dikembangkan IIIT bersifat relatif terbuka dengan memberi ruang pada berbagai ujicoba pemikiran atau ijtihad, pada bidang yang lebih praktis, segala sesuatunya dirancang sedemikian rupa seolah telah jelas sejelas-jelasnya. Menjadi bagian dari promosi, bahwa perbankan Islam adalah perbankan berbasis sistem bagi hasil, bukan perbankan berbasis bunga yang dinilai "melanggar ajaran Islam" yang menyebabkan pelaku maupun nasabahnya menanggung konsekuensi dosa. Demikian pula, produk asuransi yang sesuai dengan ajaran Islam adalah yang dikeluarkan perusahaan yang berlabelkan Islam. Selain itu, jatuh pada keharaman karena di dalamnya ada praktik garar (ketidakjelasan pengelolaan dana) dan semacamnya. Begitu juga, perusahaan MLM yang sesuai dengan ajaran Islam adalah perusahaan MLM Syari ah. Perusahaan MLM lain yang didirikan oleh non-Muslim atau Muslim yang tidak menunjukkan jatidiri syari'ahnya dinyatakan sebagai "tidak sesuai dengan ajaran Islam".

Realitas pasar seperti di atas pada akhirnya menyeret Islamiasi Ilmu Ekonomi ke arah yang sangat pragmatis. Pendidikan Ekonomi Islam yang mulai diajarkan - baik lewat lembaga pendidikan spesialis Ekonomi Islam maupun lewat universitas "sekuler" yang membuka program pendidikan Ekonomi Islam - diarahkan untuk memenuhi kebutuhan tenaga ahli di "perusahaan-perusahaan Islami”: perbankan, asuransi dan lainnya yang berlabel syari'ah itu. Pendekatan yang digunakan, bisa diduga, bukan lagi pendekatan ilmiah yang memberi ruang bagi penelaahan berbagai teori dan konsep secara terbuka, melainkan "pendekatan pasar". Para mahasiswa dididik untuk memahami, menguasai dan bisa mempraktekkan ilmu Ekonomi Islam yang bentuknya dianggap telah jelas dan baku. Mereka tidak dididik untuk bertanya secara kritis, menggali sekian banyak teori secara terbuka, kemudian memutuskan teori mana yang akan dipegang secara praktis atau bahkan merumuskan teori baru berdasarkan percobaan dan penelitian empirik mereka.

Nuansa hegemonikpun menjadi demikian jelas terlihat. Gerakan Islamisasi Ilmu Ekonomi, pada akhirnya diarahkan oleh kepentingan politik-ekonomi tertentu. Ia bergeser ke arah perjuangan politik-ekonomi sektarian; Ekonomi Islam dibangun dan dikembangkan demi kepentingan "umat Islam". Bukan lagi murni sebagai gerakan intelektual yang memihak kepada kebenaran itu sendiri ataupun untuk mengabdi pada kemanusiaan secara lebih luas. Barangkali kita memberi permakluman dengan mengetengahkan realitas umat Islam yang terpuruk secara ekonomi yang karenanya membutuhkan "gerakan kebangkitan".

Pengembangan Ilmu Ekonomi Islam dan beragam institusi ekonomi Islam di atas, merupakan upaya untuk mengatasi masalah dimaksud. Tentu argumen seperti ini sah-sah saja. Akan tetapi perlu diingat, bahwa keterpurukan ekonomi maupun kemiskinan adalah persoalan kemanusiaan tanpa memandang agama dan ideologi; pada kasus Indonesia, ia di alami oleh warga negara Muslim seperti di Jakarta yang terdesak oleh konglomerasi dan praktik bisnis curang, maupun oleh warga negara non-Muslim di Irian Jaya yang termiskinkan oleh 
sistem eksploitatif yang tak ramah adat dan lingkungan. Sektarianisme yang mengatasnamakan penguatan identitas keagamaan, jelas bukan pilihan bijak. Terlebih, secara mendasar Islam memesankan semangat universalis, semangat menjadi "rahmat bagi semesta".

Persoalan lainnya adalah, siapa sebenarnya yang dimaksud dengan "umat Islam"? Agaknya, pada kasus ini, seringkali yang dimaksud dengan umat Islam adalah para pemilik modal yang membutuhkan trik-trik tertentu supaya produk mereka bisa laku, bisnis mereka berkembang dan akumulasi modal mereka semakin membukit. Lewat baju perusahaan-perusahaan Islami, sentimentalitas, fanatisme dan gairah keagamaan masyarakat Islam tampaknya memang cukup mudah untuk dimanfaatkan demi tujuan ini. Secara pedas mungkin bisa dikatakan, inilah "kapitalisme yang bertopengkan Islam".

Secara kritis, meminjam istilah Michael Foucault ${ }^{16}$, tokoh post modernisme asal Perancis yang mengembangkan kritik nalar politik, dari sisi-sisi tertentu, kasus pengembangan ekonomi Islam di Indonesia dapat dibaca sebagai fenomena penggunaan kekuasaan dalam membangun pengetahuan, untuk kepentingan kekuasaan tersebut. Sekelompok orang yang mengatasnamakan umat Islam, menempatkan diri sebagai rezim-rezim produksi kebenaran, menuju docility/ utility (penundukan/ pemanfaatan) masyarakat lain. Baik karena motif egoisme murni demi akumulasi kekayaan, maupun karena kesadaran untuk memperjuangkan dominasi umat Islam atas umat lainnya.

\section{Menilai Peradaban dan Ilmu Pengetahuan Barat}

Peradaban dan ilmu pengetahuan Barat modern, di satu sisi, semestinya tidak dianggap sebagai sesuatu yang "khas" dan "orisinal" Barat, mengiringi keberhasilan Renaissance di Perancis dan Revolusi Industri di Inggris. Sebaliknya, pandangan yang jernih akan menyatakan, ia adalah sejenis percampuran aneka warisan sejarah. Di dalamnya ada kontribusi kebudayaan Yunani, baik dalam bentuk-bentuk sastra mitologisnya, maupun dalam bentuk filsafat rasionalnya. Juga ada pengaruh Kristen, dalam bentuknya yang paling spiritualis ala gnostisisme Katholik hingga etika Protestan ala Calvinis - Max Weber menyebutnya sebagai

${ }^{16}$ Michel Foucault adalah seorang pemikir besar Perancis abad ke-20, lahir di Poitiers, 15 Oktober 1926. Pendidikan akademisnya dilalui di Ecole Normale Superiuere (Paris) bidang filsafat dan psikologi. Tugas akademis yang pernah Ia emban adalah Direktur Departemen Filsafat di University of Clermont-Ferrand dan University of Vincennes (1960). Ia juga pernah menjadi professor bidang Sejarah Sistem Pemikiran di College de France. Juga pernah mengajar selama bertahun-tahun di negara Arab Maghrib (terutama Tunisia). Pada 25 Juni 1984, Ia meninggal dunia di Paris. Peter Beilharz (2002), Teori-Teori Sosial Observasi Kritis Terhadap Para Filosuf Terkemuka terjemahan Sigit Jatmiko dari judul asli Social Theory: A Guide to Central Thinkers ( Yogyakarta: Pustaka Pelajar ), p.127-136. 
akar kapitalisme, dan kapitalisme inilah yang menggiring peradaban Barat pada keberlimpahan materi. Dan tak layak dilupakan, kontribusi peradaban Islam yang menjadi jembatan antara peradaban Barat modern dengan khazanah Yunani, khususnya lewat pikiran-pikiran para filosof semacam Ibnu Rusyd. Meminjam istilah Goenawan Muhammad, peradaban Barat - sebagaimana juga peradaban Islam - lebih tepat disebut sebagai "sebuah agregat besar".

Di sisi lain, perlu juga ditegaskan bahwa peradaban Barat bukanlah sesuatu yang telah selesai dalam keseragaman ataupun berakhir dalam wujud yang jelassejelasnya. Sebaliknya, peradaban Barat adalah wilayah dimana dialektika terus berlangsung. Ia adalah tempat dimana pergulatan antar berbagai pemikiran tak henti berkecamuk. Sepanjang sejarahnya, dua hal berlawanan senantiasa saling menggugat: Logos dan Mitos, agama dan filsafat, rasionalisme dan empirisisme, idealisme dan materialisme, obyektivisme dan subyektivisme, bahkan juga fundamentalisme dan perenialisme.

Pada titik-titik tertentu, peradaban Barat memang cukup sering terseret ke lorong sejarah yang penuh tragedi. Ketika agama dan gereja demikian berkuasa - di suatu masa yang dikenal sebagai "the middle dark age", akal budi manusia tak henti dinistakan. Atas nama Tuhan, sesuatu yang berbeda disingkirkan dan dihabisi: agama dan pemeluk agama lain, maupun ilmu pengetahuan dan ilmuan yang "membangkang". Inkuisisi dan ekskomunikasi menjadi kata kunci yang merindingkan bulu kuduk. Demikian pula, ketika peradaban Barat memasuki tahapan modern; suatu fase dimana ia begitu superior dibandingkan peradaban manapun. Apa yang dulu dicengkeram agama kini justru teramat berkuasa: logos, rasionalitas, ilmu pengetahuan, sains. Maka agamapun dicerca, spiritualitas dilecehkan, etika dan estetika - seperti disebutkan Richard I. Bernstein ${ }^{17}$ dianggap sekadar ilusi, fiksi, prasangka, fantasi, imajinasi, superstisi - dengan kata lain, bukan kebenaran.

Ketika proyek Pencerahan mulai digulirkan dengan sains (baca: ilmu pengetahuan modern) sebagai tulang punggung, ada banyak janji seperti dituliskan Marquis de Condorcet dalam karyanya yang dianggap sebagai manifesto “janji-janji Pencerahan Perancis, bahwa penyebaran kekuatan-kekuatan dalam masyarakat akan membawa kemajuan yang tidak sekadar berupa pertumbuhan ekonomi dan pembangunan material, namun terwujudnya tujuan sejarah, yakni kesempurnaan tak terbatas umat manusia yang juga bersifat etis. Lebih jauh, di masa depan rasio yang berwujud dalam sains akan menghancurkan ketimpangan-ketimpangan kultural, politis, dan ekonomis di antara berbagai bangsa, menyempurnakan kemampuan manusia, mewujudkan kebahagiaan pribadi dan kesejahteraan umum, menyingkirkan diskriminasi seksual, dan menghapus perang dari muka bumi. ${ }^{18}$

${ }^{17}$ F. Budi Hardiman (1994), "Ilmu-ilmu Sosial dalam Diskursus Modernisme dan Pasca-Modernisme”, dalam Jurnal Ilmu dan Kebudayaan Ulumul Qur'an No. 1 Vol. 5, Jakarta: LSAF, Tahun 1994

${ }^{18}$ Ibid. 
Pada kenyataannya, di balik kemegahan material yang memang berhasil diwujudkan proyek rasionalisme, ada sederet cerita kelabu. Mulai dari fasisme di Italia, barbarisme Nazi dengan proyek Holocaust-nya, tirani Leninisme yang menyengsarakan jutaan rakyat Rusia dan negeri-negeri satelitnya, pemboman di Nagasaki dan Hiroshima, hingga yang mutakhir: perang babak I Irak-Amerika Serikat dan sekutunya, pembersihan etnis di Bosnia dan perang babak II IrakAmerika Serikat dan sekutunya. Belum lagi menghitung rangkaian krisis spiritual dan kehampaan makna hidup, yang pada titik ekstrim memicu kemunculan sekte-sekte yang terkenal dengan bunuh diri massalnya semacam kelompok David Koresh. Bahkan ketika ideologi yang sama-sama lahir dari proyek rasionalisme -kapitalisme di satu pihak dan komunisme di seberangnya - coba dipindahkan ke wilayah dan ruang peradaban lain, berbagai kejadian tragis juga terjadi. Di Kamboja, dimana komunisme sempat merajalela, sepertiga penduduk negeri itu tewas terbantai. Di Brazil, sebagaimana digambarkan Peter L. Berger lewat Piramida Kemiskinannya, sekian banyak orang terperangkap dalam kemiskinan kronis akibat ujicoba kapitalisme oleh rejim lokal dukungan negara-negara Barat. Di Cina yang mengujicoba komunisme, jutaan orang tewas oleh teror. Tak luput, di negeri-negeri Islam dimana proyek rasionalisme juga coba diterapkan, muncul beragam masalah. Di satu sisi, negeri-negeri itu tak kunjung modern sebagaimana negeri-negeri Barat. Alam merekapun malah mengalami kerusakan parah yang mengancam keberlangsungan hidup generasi selanjutnya. Sementara di sisi lain, kebanyakan anggota masyarakat yang seolah mengalami keterasingan dan ketercerabutan dari akar kebudayaannya. Sesuatu yang kemudian memicu konflik berkepanjangan, antara pendukung rasionalisme modern dan pendukung gerakan kembali pada identitas lama, yaitu identitas Islam.

Jelas, ilmu pengetahuan Barat, atau sains modern yang berbasis rasionalisme yang seringkali mengobsesikan kemutlakan, keserbamencakupan dan keuniversalan, patut untuk dipermasalahkan. Artinya, pada titik ini, kritik para penggagas Islamisasi Ilmu Pengetahuan memiliki kebenaran. Namun, sebagaimana disebut dimuka, peradaban Barat adalah sebuah ruang dimana dialektika pemikiran tak pernah berkesudahan. Ia memiliki mekanisme kritik diri. Selalu ada upaya memperbaharui dan menyempurnakan apa yang dianggap cacat. Maka pada titik ini, para penggagas Islamisasi Ilmu Pengetahuan yang merekomendasikan semacam pemisahan antara yang Islam dan Bukan Islam, jelas keliru. Mereka, dengan begitu, mendindingi masyarakat Muslim dari kearifan dan sekian nilai positif peradaban dan ilmu pengetahuan Barat yang muncul dari mekanisme kritik dan dialektika penyempurnaan diri. Padahal, sikap seperti ini jelas bertentangan dengan etos para filosof dan ilmuan Muslim klasik yang konsisten membuka diri, dengan penuh hormat pada kebenaran dari manapun datangnya.

Sebagai misal, dalam diskursus intelektual Barat muncul gerakan postmodernisme yang mencoba mempertanyakan dan menggugat rasionalisme dan modernisme dalam segala seginya, sebagaimana dirintis Friederich Nietzsche 
dan kemudian dilanjutkan oleh intelektual semacam Jacques Derrida, Michael Foucault dan lainnya. Kita misalnya juga melihat identifikasi F. Budi Hardiman mengenai beberapa arus pemikiran dalam ilmu-ilmu sosial yang mencoba memperbaiki cacat-cacat modernisme dengan proyek rasionalismenya. Arusarus pemikiran tersebut, di antaranya adalah Teori Tindakan yang digagaskan Weber. Melalui teori ini, sekalipun Weber tak berhasil menghindar sepenuhnya dari tendensi saintisme, ia bisa menghadirkan ruang bagi ekspresi fenomenal dari makna-makna, semacam "keselamatan abadi", "kebaikan hati" dan "kerendahan hati". Artinya, subyektivisme kembali mendapatkan ruang. Kemudian, ada pula Teori Fenomenologi yang digagaskan tokoh semacam Husserl dan Alfred Schutz. Teori ini menolak obyektivisme saintisme, yang salah satu implementasinya adalah sikap natural yang naif. Sebaliknya, teori ini menegaskan bahwa model pengembalian obyektivitas pada dunia penghayatan langsung para pelaku sosial. Singkat kata, lewat fenomenologi persoalan makna, subyektivisme, refleksi dan self-questioning mendapat tempat dalam tradisi ilmiah. Teori-teori lainnya adalah Teori Kritis yang dipelopori Jurgen Habermas dengan Mazhab Frankfurt-nya, juga oleh Antonio Gramsci yang mengurai konstruk hegemoni, ataupun Michael Foucault yang mendeskripsikan nalar politik dan menguraikan keterkaitan antara power dan knowledge. ${ }^{19}$

Sementara dalam lapangan ilmu alam, apa yang dilakukan oleh ilmuan seperti Fritchof Capra yang membawa spiritualitas Timur ke dalam fisika, patut diapresiasi. Demikian pula dengan kemunculan mazhab psikologi transpersonal yang diusung oleh Carl Gustav Jung. Mazhab psikologi ini, kita tahu, memberi tempat kepada ruh manusia yang bersifat non-material ke dalam perdebatan ilmiah.

\section{Seputar Alternatif}

Agaknya, kita bisa bersepakat bahwa sebagai bagian dari umat Islam, kita memiliki kewajiban untuk menyelesaikan persoalan-persoalan di tingkat internal umat Islam. Sebagaimana kita sebagai bagian dari umat manusia juga memiliki tanggung jawab untuk turut mengatasi persoalan-persoalan peradaban, khususnya yang diakibatkan oleh penerapan ilmu pengetahuan Barat modern. Kita juga agaknya bisa sepakat, bahwa salah satu persoalan mendasar di kalangan umat Islam - seperti diungkapkan Abdul Hamid Abu Sulayman - adalah persoalan sistem berpikir. Sehingga, salah satu langkah strategis yang mesti diambil adalah semacam rekonstruksi pemikiran. Persoalannya adalah, pilihan apakah yang mesti diambil?

Gagasan Islamisasi Ilmu Pengetahuan yang dikemukakan al Faruqi dan

${ }^{19}$ Michel Foucault (1980), Power/Knowledge:Selected Interviews and Other Writings 1772-1977, Collin Gordon (ed.). ( New York: Pantheon Books),,p.176; Haryatmoko (2003), Etika Politik dan Kekuasaan (Jakarta: Penerbit Buku Kompas), p.227. 
para koleganya, sebagaimana ditelusuri di atas, banyak memiliki sisi problematik. Menengok pada berbagai pemikiran pokok yang sering dikemukakan, seperti kembali kepada Islam, Islam mencakup segalanya, Al Qur'an dan As Sunnah harus selalu dijadikan rujukan dalam mengembangkan Ilmu Pengetahuan, tak ada pertentangan antara akal dan wahyu, nalar epistemologis yang digunakan para pengusung ide ini - meminjam klasifikasi yang dibuat Muhammad Abid al Jabiri - adalah nalar bayani. ${ }^{20}$ Berdasar nalar bayani ini, pilihan metodologis yang diambil akan berkecenderungan serba mengedepankan teks.

Sisi problematik tersebut muncul dari ketidakjelasan inheren yang terkandung dalam pikiran-pikiran pokok yang diungkapkan di atas. Misalnya, apakah yang dimaksud kembali kepada pada Islam? Apakah maksudnya kita kembali pada tradisi berpikir yang selama ini dikembangkan para pemikir Muslim klasik? Kalau jawabannya iya, kepada tradisi pemikir Muslim klasik yang mana kita mesti kembali? Demikian pula, apa yang dimaksud dengan pernyataan Islam mencakup segalanya dan "Al Qur'an dan As Sunnah harus selalu dijadikan rujukan dalam mengembangkan Ilmu Pengetahuan"? Apakah itu berarti teori-teori ilmu pengetahuan dalam berbagai disiplin ilmu seperti Fisika, Ekonomi dan Sosiologi telah dinyatakan di dalam Al Qur'an sehingga kita tinggal mengambilnya saja? Jika kita menjawab iya, apakah kita berarti mengatakan Al Qur'an merupakan Kitab Fisika, Kitab Ekonomi dan Kitab Sosiologi? Juga, apa yang dimaksud dengan "tidak ada pertentangan antara akal dan wahyu"? Apakah itu berarti apa yang dibenarkan oleh akal pasti akan dibenarkan oleh wahyu? Atau sebaliknya, apa yang secara tersurat dinyatakan oleh wahyu, pasti bisa dibenarkan oleh akal? Kalau begitu maksudnya, rasanya tidak akan mungkin ada pertentangan antara kalangan fuqoha dan kalangan filosof, karena toh keduanya akan berjumpa pada titik kebenaran yang sama. Atau justru maksud pernyataan tersebut adalah akal tidak boleh menyalahi apa yang tersurat dalam wahyu? Dan jika ada perbedaan antara produk akal manusia dengan yang tersurat dalam wahyu, maka sesungguhnya akal manusialah yang salah berpikir baik karena terselubungi oleh hawa nafsu maupun digelincirkan oleh setan?

Problema tersebut akan menjadi semakin kompleks, ketika nalar bayani, pada praktiknya, tak bisa dilepaskan dari nalar politik yang mengarahkan masyarakat Muslim agar tunduk dan taat kepada penguasa yang merupakan "wakil Tuhan di muka bumi", seotoriter dan sezalim apapun dia. Peletakan teks yang diasumsikan absolut dan mencakup segalanya pada posisi sentral dalam sistem berpikir masyarakat Muslim, pada akhirnya akan menggiring masyarakat Muslim pada ikatan dan batasan-batasan yang dibuat oleh teks itu, dalam setiap ruang kehidupannya. Sementara pada saat bersamaan, yang memiliki otoritas untuk membuat batasan dan ikatan itu adalah para "ulama" dan "ulul amr";

${ }^{20}$ Muhammad Abid al-Jabiri (1992), Bunyah al-Aql al-Arabi: Dirasah Tahliliyah li Nuzhum al-Ma'rifah fi Saqafah al-Arabiyah ( Beirut: Markuz Dirasah al-Wihdah alArabiyah). 
dua kelompok elit di kalangan masyarakat Muslim yang sering berkoalisi demi melanggengkan struktur kekuasaan.

Oleh karena itu, Islamisasi Ilmu Pengetahuan berdasarkan nalar bayani yang cenderung dimaknai sebagai penaklukan "cara memproduksi dan mengembangkan ilmu pengetahuan" kepada teks yang otoritas penafsirannya berada di tangan "ulama" dan "ulul amr", akan menggiring wilayah ilmu pengetahuan tersebut kepada kooptasi negara. Dan sebagaimana masa kegelapan Eropa di masa lalu, ketika buah pemikiran Galileo Galilei dinilai salah dan benar oleh penguasa agama yang mengatasnamakan Tuhan - dan bukannya oleh pengujian ilmiah yang jujur dan jernih - seperti itu pulalah yang membayang di depan mata kita.

Semestinya, rekonstruksi pemikiran di kalangan masyarakat Muslim tidak diarahkan untuk mewujudkan umat yang superior dan dominatif secara politik dan ekonomi - sekalipun itu merujuk pada masa lalu yang dipandang sebagai "masa kejayaan dan kegemilangan Islam". Persoalannya, logika superioritas dan dominasi adalah logika kekuasaan, logika politisi. Karena ketika logika seperti ini yang menjadi arus utama, maka sesungguhnya yang paling banyak diuntungkan adalah pihak-pihak yang ada di puncak kekuasaan. Yaitu para cerdik pandai yang lihai menyiasati jalur-jalur politik demi obsesi pribadi dan kelompok. Sementara mayoritas masyarakat Muslim, sekalipun mereka tidak ditindas oleh "kekuatan asing", mereka akan ditindas oleh "saudara seiman yang berkuasa".

Sebaliknya, rekonstruksi itu mesti mengarah pada ideal-ideal Islam yang sejatinya bersifat universal, semisal terwujudnya keadilan, tersebarnya kedamaian dan kasih sayang kepada seluruh umat manusia, juga terciptanya kesetaraan, kebersamaan, tolong menolong dan penghormatan hak asasi antar umat manusia. Lebih tegas, rekonstruksi pemikiran di kalangan kaum Muslimin, mesti mengarah pada pengembangan model berpikir yang berbasis akal sehat dan berorientasi pada semangat menghadirkan rahmat kepada semesta alam. Bukan model pemikiran yang membawa umat Islam kian eksklusif, dengan kesadaran "mesti terpisah dari peradaban umat manusia yang jahiliyah", dan berbasis ketundukkan kepada "para ulama dan penguasa yang mengatasnamakan Tuhan".

Terkait dengan ide di atas, menjadi penting bagi kita - sekalipun bisa jadi jargonnya sama-sama kembali kepada Islam - tetapi yang kita lakukan adalah secara jernih dan lapang dada menggali kerak-kerak sejarah peradaban kita. Menggali dan menghidupkan kembali kearifan-kearifan yang pernah menjadi bagian dari tradisi umat Islam klasik, sekaligus membuang "kegelapan-kegelapan sejarah" yang merupakan sejenis "kegagalan dalam mengimplementasikan Islam yang ideal ke dalam titik koordinat ruang dan waktu tertentu". Memang teramat sulit, karena lagi-lagi pendefinisian "kearifan" dan "kegelapan sejarah" akan sangat tergantung pada subyektivitas kita. Sebab itu, kerendahan hati dan sikap terbuka menjadi prasyarat mutlak bagi keberhasilan upaya ini.

Selanjutnya, perlu dikemukakan jalan lain rekonstruksi pemikiran, yang dibangun berdasarkan beberapa asumsi-asumsi dasar berikut: 
A. Teks (nas) itu terbatas. Ada wilayah yang tidak diatur oleh teks, dan itu menjadi wilayah kerja akal budi manusia. Abu Ishaq al Syathibi juga menyatakan bahwa agama itu adalah sebatas apa yang dikemukakan. Yang tidak dikemukakan, tidak bisa dimasukkan begitu saja kepada wilayah agama. Karena itu, wilayah ilmu pengetahuan tidak bisa dikaitkan langsung kepada teks. Ia mesti dimasukkan ke dalam wilayah non-agama, yang menjadi ruang kerja akal budi manusia.

B. Hubungan akal dan wahyu adalah hubungan yang sinergis, saling melengkapi. Ada wilayah yang merupakan otoritas teks, ada pula yang merupakan otoritas akal.

C. Teks pada dasarnya memiliki substansi. Substansi teks ini bisa juga disebutkan sebagai komitmen Tuhan bagi kemaslahatan manusia, atau nilai-nilai kebajikan yang universal. ${ }^{21}$

D. Akal manusia memiliki kemampuan untuk menangkap komitmen Tuhan maupun nilai-nilai universal di balik teks. Akal juga memiliki kemampuan untuk merumuskan sistem etika berbasis substansi teks.

E. Alam ini adalah ayat Tuhan yang lain di luar Teks Suci. Di dalamnya terbangun hukum kausalitas yang batas-batas dan hakikatnya hanya Tuhan yang Tahu. Ketidakterbatasan ini pada dasarnya merefleksikan ketakterjangkauan wujud Tuhan oleh akal budi manusia. Apa yang berhasil dikuakkan manusia dari alam - atau dalam bahasa lain, kausalitas yang teridentifikasi kemudian disistematisasi oleh akal manusia - adalah "ilmu pengetahuan". Batas wilayah kerja akal manusia adalah puncak tertinggi dari kemampuan akalnya; sesuatu yang hanya diketahui Tuhan sendiri. Manusia memiliki hak untuk mengaktualisasikan potensi akalnya sedalam dan seluas mungkin, untuk menguak rahasia alam sebanyak-banyaknya demi kemaslahatan manusia.

F. Hubungan Teks dengan ilmu pengetahuan adalah sebagai berikut: Teks Suci merupakan sumber inspirasi bagi Sistem Etika yang dirumuskan oleh akal, dan Sistem Etika inilah yang kemudian menjadi basis pengembangan Ilmu Pengetahuan, sehingga pada tingkat praktis, Ilmu Pengetahuan bisa selaras dengan komitmen Tuhan dan nilai-nilai kebajikan universal. Filsafat, pada titik ini, menjadi semacam basis metodologis. Dalam artian, model berpikir yang rasional mesti mewarnai proses pengembangan ilmu pengetahuan.

G. Sistem Etika ini sangat mungkin menjadi wilayah pertemuan antar berbagai umat beragama dan sistem kebudayaan yang berbeda-beda. Dalam bahasa perenialis, inilah "wilayah esoteris yang menjadi titik temu antar agamaagama”.

H. Ilmu Pengetahuan, dengan demikian, dikembangkan berlandaskan Sistem Etika ini. Umat Islam bisa mengambil ilmu pengetahuan dari mana saja,

${ }^{21}$ Al-Syatibi (Tanpa Tahun), Al-Muwafaqat fi Usul al-Syariah (Kairo: Maktabah al-Tijariyah), II: 4-5. 
kebudayaan dan peradaban apapun, sejauh selaras dengan Sistem Etika yang tersebut. Pada titik ini, ilmu pengetahuan yang diproduksi umat Islampun menjadi sesuatu yang terbuka untuk dimanfaatkan oleh kebudayaan dan peradaban lain.

Berdasarkan asumsi-asumsi di atas, tawaran alternatif terhadap model Islamisasi Ilmu Pengetahuan yang cenderung legalistik dan sektarianistik, adalah rekonstruksi Ilmu pengetahuan berbasis etika. ${ }^{22}$ Agak mirip dengan spiritualisasi ilmu pengetahuan yang kini mulai berkembang di dunia Barat, dengan tokoh semacam Fritchof Capra dalam Fisika dan Carl Gustav Jung dalam psikologi. Letak perbedaannya, sistem etika yang di kembangkan ini, mengacu pada tradisi intelektual Islam klasik Sekalipun hasilnya bisa sama dengan sistem etika yang dikembangkan para pemikir Barat, proses perumusan sistem etika tersebut secara historis mengikuti jalur yang khas Islam, seperti dengan memanfaatkan tradisi tafsir dan ushul fiqh. Tentu saja, perlu ditegaskan bahwa, pertama, tradisi klasik yang diambil adalah tradisi klasik yang telah direvitalisasi. Unsur-unsur otoritarianistik dan kebekuan dalam disiplin tafsir dan ushul fiqh, perlu disisihkan. Sehingga hasilnya adalah bangunan sistem etika yang emansipatif, liberatif dan berorientasi pada maslahat manusia secara universal. Kedua, perlu juga diciptakan ruang bagi pengayaan dari kearifan yang dihadirkan tradisi dan peradaban lain, semacam hermeneutika.

Dengan model tersebut, rekonstruksi ilmu pengetahuan berbasis etika akan menjadi sebuah kerja lintas peradaban, dengan sifat yang terbuka dan dialogis. Ilmu pengetahuan yang dihasilkanpun akan menjadi milik bersama antarperadaban, yang dapat dan bebas dimanfaatkan oleh siapa saja, demi kemaslahatan bersama.

\section{Penutup}

Satu hal yang kiranya perlu tetap disadari, adalah bahwa setiap hasil pemikiran manusia, selalu bersifat historis: terikat dengan ruang dan waktu yang melingkungi sang pemikir. Gagasan Islamisasi Ilmu Pengetahuan, tentulah memiliki kebenaran-kebenaran tertentu sesuai dengan bingkai ruang dan waktunya. Ia, betapapun merupakan sebuah upaya solusi terhadap berbagai problema keumatan yang memang nyata keberadaannya.

Menjadi penting bagi umat Islam masa kini, pada satu sisi, mengapresiasi dan membuka ruang dialog bagi gagasan Islamisasi Ilmu Pengetahuan, sebagai suatu sumbangan sekelompok sarjana Muslim terhadap peradaban umat manusia. Pada sisi lain, menjaga agar gerakan tersebut berada pada bingkai kerja ilmiah,

${ }^{22}$ Ian G. Barbour (2002), Juru Bicara Tuhan antara Sains dan Agama, terjemahan E.R. Muhammad dari judul asli When Science Meets Religion, Strangers or Partners ( Bandung: Mizan), p.82-100. 
yang ukuran kebenarannya adalah sejauh mana ia bisa konsisten terhadap premispremis dasar yang dibangunnya. Juga sejauh mana ia bisa mengatasi verifikasi ilmiah dari para pengkritiknya. Tentu saja, seberapa jauh ia bisa memberi maslahat bagi umat manusia; setidaknya memecahkan persoalan-persoalan yang dijadikan isu utama. Sangat naif, jika kemudian terjadi penggeseran orientasi gerakan ini, dari yang sifatnya ilmiah menjadi politis dan ideologis. Sehingga gagasan tersebut menjadi gagasan yang tertutup karena dianggap final kebenarannya atau bahkan diyakini tidak bisa salah karena berasal dari Tuhan Yang Maha Benar.

\section{DAFTAR PUSTAKA}

Alatas,Syed Farid (1994). "Agama dan Ilmu-ilmu Sosial”, dalam Jurnal Ilmu dan Kebudayaan Ulumul Qur'an No. 2 Vol. 5 Tahun 1994.

Alim, R.H.A. Sahirul (1999). Menguak Keterpaduan Sains, Teknologi dan Islam. Yogyakarta: Titian Ilahi Press.

Anwar, Chairil (2000). Islam dan Tantangan Kemanusiaan Abad XXI . Yogyakarta: Pustaka Pelajar.

Barbour, Ian G. (2002). Juru Bicara Tuhan antara Sains dan Agama, terjemahan E.R. Muhammad dari judul asli When Science Meets Religion, Strangers or Partners. Bandung: Mizan.

Beilharz, Peter (2002). Teori-Teori Sosial Observasi Kritis Terhadap Para Filosuf Terkemuka terjemahan Sigit Jatmiko dari judul asli Social Theory: A Guide to Central Thinkers. Yogyakarta: Pustaka Pelajar.

Brohi,A.K. (1988). "Islamization of Knowledge: A First Step to Integrate and Develope the Muslim Personality and Outlook", dalam Islam: Source and Purpose of Knowledge, Herndon, Virginia, USA: International Institute of Islamic Thought.

Dewantoro, Setyo Hajar (2003). "Tuhan dan Agama, Diskursus Filsafat Barat", Jurnal Fikih Rakyat No. 1 Vol. I, Cirebon: Fahmina Institute, tahun 2003.

Dewantoro, Setyo Hajar. Islamisasi Ilmu Pengetahuan Suatu Tinjauan Kritis dikutip dari http://www.fahmina.org/telaah\%20ut1.htm, accessed 6 Februari 2007.

Elmessiry, Abdelwahab M. (1997). "Modernity, Immanence and Deconstruction", dalam The American Journal of Islamic Social Sciences Volume 14 No. 1, IIIT.

Faruqi,Isma'il Raji al- (1988). "Islamization of Knowledge: Principles, and Prospective”, dalam Islam: Source and Purpose of Knowledge, Herndon, Virginia, USA: International Institute of Islamic Thought.

Foucault, Michel (1980). Power/Knowledge:Selected Interviews and Other Writings 1772-1977, Collin Gordon (ed.). New York: Pantheon Books. 
Yusdani: Islamisasi Model ...

Hardiman, F. Budi (1994). "Ilmu-ilmu Sosial dalam Diskursus Modernisme dan Pasca-Modernisme”, dalam Jurnal Ilmu dan Kebudayaan Ulumul Qur'an No. 1 Vol. 5, Jakarta: LSAF, Tahun 1994

Haryatmoko (2003). Etika Politik dan Kekuasaan. Jakarta: Penerbit Buku Kompas.

Jabiri, Muhammad Abid al- (1992). Bunyah al-Aql al-Arabi: Dirasah Tahliliyah li Nuzhum al-Ma'rifah fi Saqafah al-Arabiyah. Beirut: Markuz Dirasah alWihdah al-Arabiyah.

Kazi,M.A. (1988). Islamization of Modern Science and Technology dalam Islam: Source and Purpose of Knowledge, Herndon, Virginia, USA: International Institute of Islamic Thought.

Keraf, A. Sonny (1995).” Pasar Bebas, Keadilan dan Peran Pemerintah, Telaah atas Etika Politik Ekonomi Adam Smith", Majalah Prisma No. 9, Jakarta: LP3ES, September 1995

Khan, Muhammad Akram, "The Role of Government in The Economy", dalam The American Journal of Islamic Social Sciences Volume 14 Nomor 2.

Markam, Roekmono (1980). "Ekonomi Post Robbins", Majalah Prisma No. 1 Edisi Januari 1980. Jakarta: LP3ES.

Nasr, Seyyed Hosein (1994). Menjelajah Dunia Modern Bimbingan untuk Kaum Muda Muslim. Bandung: Penerbit Mizan.

Shadr, Muhammad Baqr ash- (1991). Falsafatuna., Bandung: Penerbit Mizan.

Sulayman, Abdul Hamid Abu (1993). Crisis in the Muslim Mind, Herndon, VA:IIIT.

Sulayman, Abdul Hamid Abu (1988). "Islamization of Knowledge: A New Approach Toward Reform of Contemporary Knowledge", dalam Islam: Source and Purpose of Knowledge, Herndon, Virginia, USA: International Institute of Islamic Thought.

Suseno, Franz Magnis (1999). Pemikiran Karl Marx Dari Sosialisme Utopis ke Perselisihan Revisionisme. Jakarta: Penerbit Gramedia.

Syatibi, Al- (tt). Al-Muwafaqat fi Usul al-Syari'ah.Kairo: Maktabah alTijariyah. 